\title{
Penyuluhan Prinsip-prinsip Good Manufacturing Practices (GMP) pada Home Industry Olahan Singkong dan Ubi di Desa Tokelan, Kecamatan Panji, Kabupaten Situbondo
}

\section{Counceling of Good Manufacturing Practices (GMP) Principles in Cassava and Sweet Potato Home Industry in Tokelan Village, Panji District, Situbondo Regency}

\author{
Gema Iftitah Anugerah Yekti ${ }^{1)}$, Yasmini Suryaningsih ${ }^{2)}$ \\ Email: ${ }^{1}$ gemaiftitah31@gmail.com; ${ }^{2}$ jasminumsambac@gmail.com \\ ${ }^{1,2}$ Universitas Abdurachman Saleh Situbondo
}

\begin{abstract}
Tokelan Village is one of the villages in Panji District that has several traditional home industries. Some home industries that are still traditional are the home industry of Jaya cassava chips and Karang Mas Mbak Nur's home industry. Both of them haven not applied GMP principles in their business. The production environment of both of them also tends to be simple by utilizing the yard as a place of production. The layout of the production process was not in accordance with the principles of GMP. This happened because of their limited knowledge and skills regarding GMP principles. Therefore, counseling about the application of GMP principles needs to be done to improve product quality and safety. In addition, GMP principles can also guarantee the health and safety of workers. Counseling on the application of GMP principles is carried out through lecture, discussion, and mentoring methods. The material to be presented includes the concept of food safety, the dangers associated with the production of processed food, the principles of GMP, and the application of the principles of GMP.
\end{abstract}

Keywords: food safety, GMP, GMP principles

\begin{abstract}
Abstrak : Desa Tokelan merupakan salah satu desa yang ada di Kecamatan Panji yang memiliki beberapa home industry yang masih tradisional. Beberapa home industry yang masih tradisional yaitu home industry keripik singkong Jaya dan home industry Karang Mas Mbak Nur. Keduanya masih belum menerapkan prinsip-prinsip GMP dalam usahanya. Lingkungan produksi dari keduanya juga masih cenderung sederhana dengan memanfaatkan pekarangan rumah sebagai tempat produksi. Tata letak proses produksi pun tidak sesuai dengan prinsip GMP. Hal tersebut terjadi karena keterbatasan pengetahuan dan keterampilan mereka tentang prinsip GMP. Oleh sebab itu, penyuluhan tentang penerapan prinsip GMP perlu dilakukan untuk meningkatkan kualitas dan keamanan produk. Selain itu, prinsip GMP juga dapat menjamin kesehatan dan keselamatan pekerja. Penyuluhan penerapan prinsip GMP dilakukan dengan metode ceramah, diskusi, dan pendampingan. Materi yang akan disampaikan meliputi konsep keamanan pangan, bahaya-bahaya yang terkait produksi pangan olahan, prinsip-prinsip GMP, serta penerapan prinsip GMP.
\end{abstract}

Kata kunci: keamanan pangan, GMP, prinsip-prinsip GMP 


\section{INTEGRITAS : Jurnal Pengabdian}

Vol 3, No 1, Juli 2019

ISSN 2580-7978 (Cetak) ISSN 2615-0794 (Online)

\section{PENDAHULUAN}

Keamanan pangan menurut UU No 18 Tahun 2012 merupakan kondisi dan upaya yang diperlukan untuk mencegah pangan dari kemungkinan cemaran biologis, kimia, dan benda lain yang dapat menganggu, merugikan, dan membahayakan kesehatan manusia serta tidak bertentangan dengan agama, keyakinan, dan budaya masyarakat sehingga aman untuk dikonsumsi. Keamanan pangan tersebut mencakup terpenuhinya kondisi pangan yang layak konsumsi yang dimulai dari teknik budidaya yang baik, cara produksi pangan olahan yang baik, hingga pangan siap dihidangkan dan dikonsumsi oleh konsumen.

Dewasa ini, masyarakat semakin sadar pentingnya menjaga kesehatan melalui konsumsi pangan yang aman, terutama bebas dari bakteri, virus, bahan kimia, serta zat-zat berbahaya lainnya. Selain itu, tingginya persaingan industri pangan olahan untuk mendapatkan simpati konsumen, tentu saja menuntut produsen untuk terus menghadirkan produk pangan olahan yang aman dan berkualitas. Untuk itu, program penjaminan mutu, berupa Good Manufacturing Practices (GMP) perlu dilakukan oleh seluruh industri produk pangan olahan tanpa terkecuali, termasuk industri rumah tangga (home industry).

GMP adalah cara produksi yang memperhatikan aspek keamanan pangan, antara lain mencegah tercemarnya pangan olahan oleh cemaran biologi, kimia, dan benda lain; mematikan atau mencegah hidupnya jasad renik patogen; dan mengendalikan proses produksi. Mengingat pentingnya penerapan prinsip-prinsip GMP, beberapa kementrian terkait telah mengeluarkan peraturan yang ketat tentang GMP. Dinas perindustrian dan perdagangan melalui Peraturan Menteri Perindustrian RI Nomor 75/M-IND/PER/7/2010 tentang Pedoman Cara Produksi Pangan Olahan yang Baik (CPPOB). Dinas pertanian pun secara spesifik mengeluarkan Peraturan Menteri Pertanian Nomor 35/Permentan/OT.140/7/2008 tentang Persyaratan dan Penerapan Cara Pengolahan Hasil Pertanian Asal Tumbuhan Yang Baik (Good Manufacturing Practices).

Desa Tokelan merupakan salah satu desa yang ada di Kecamatan Panji yang memiliki beberapa home industry yang sudah maju dan masih tradisional. 


\section{INTEGRITAS : Jurnal Pengabdian}

Vol 3, No 1, Juli 2019

Beberapa home industry yang masih tradisional yaitu home industry keripik singkong Jaya dan home industry Karang Mas Mbak Nur. Keduanya masih belum menerapkan prinsip-prinsip GMP dalam usahanya. Lingkungan produksi dari keduanya juga masih cenderung sederhana dengan memanfaatkan pekarangan rumah sebagai tempat produksi. Tata letak proses produksi pun tidak sesuai dengan prinsip GMP. Hal tersebut terjadi karena keterbatasan pengetahuan dan keterampilan mereka tentang prinsip GMP. Oleh sebab itu, penyuluhan tentang penerapan prinsip GMP perlu dilakukan untuk meningkatkan kualitas dan keamanan produk. Selain itu, prinsip GMP juga dapat menjamin kesehatan dan keselamatan pekerja.

Adapun tujuan dari pengabdian pada masyarakat ini adalah :

a. Memberikan pengetahuan pada Home industry di Desa Tokelan tentang keamanan pangan.

b. Memberikan pengetahuan pada Home industry di Desa Tokelan tentang bahaya- bahaya yang terkait dalam pengolahan pangan

c. Memberikan pengetahuan pada Home industry di Desa Tokelan tentang prinsip-prinsip GMP

d. Memberikan pelatihan/keterampilan pada Home industry di Desa Tokelan tentang cara penerapan prinsip-prinsip GMP

\section{METODE KEGIATAN}

Kerangka berpikir untuk memecahkan masalah kegiatan ini digambarkan seperti pada Gambar 1. Dari permasalahan yang muncul disusun berbagai alternatif untuk memecahkan masalah. Selanjutnya dari berbagai alternatif, dipilih alternatif yang paling mungkin dilaksanakan. Berdasarkan kerangka berpikir tersebut, maka metode dalam kegiatan ini adalah sebagai berikut 


\section{Permasalahan}

- Home industry kurang memahami konsep keamanan pangan

- Home industry kurang memahami bahaya terkait produksi pangan olahan

- Home industry kurang memahami prinsip GMP

- Home industry kurang terampil dalam penerapan prinsip GMP

\section{Tujuan Pemecahan Masalah}

- Meningkatkan pengetahuan tentang konsep keamanan pangan

- Meningkatkan pengetahuan tentang bahaya terkait produksi pangan olahan

- Meningkatkan pengetahuan tentang prinsip GMP

- Menigkatkan keterampilan dalam menerapkan prinsip GMP

\section{Alternatif Pemecahan} Masalah

- Meningkatkan pemahaman home industry tentang penerapan prinsip GMP melalui focus group discussion (FGD) dan praktik langsung

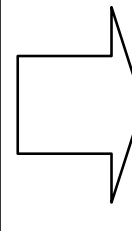

PP

(
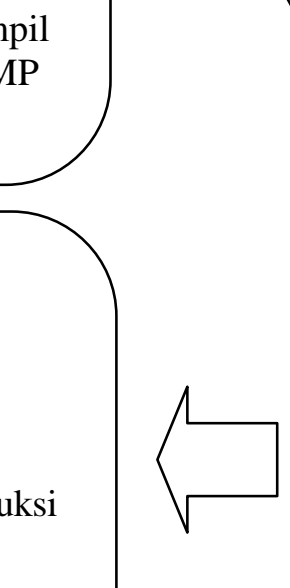

Metode Kegiatan

- FGD tentang keamanan pangan

- FGD tentang bahaya terkait produksi pangan olahan

- Pelatihan penerapan prinsip GMP

\section{Ekspektasi:}

- Peningkatan kualitas produk

- Peningkatan ruang lingkup pemasaran

Gambar 1. Bagan Skematis Metode Kegiatan 
INTEGRITAS : Jurnal Pengabdian

Vol 3, No 1, Juli 2019

ISSN 2580-7978 (Cetak) ISSN 2615-0794 (Online)

\section{HASIL DAN PEMBAHASAN}

\section{Penyuluhan Konsep Keamanan Pangan dan Pencemaran Pangan}

Kegiatan penyuluhan tentang keamanan pangan dan pencemaran pangan dilaksanakan pada tanggal 20 April 2019. Penyuluhan diikuti oleh pemilik dan karyawan home industri kripik singkong Jaya dan Karang Mas Mbak Nur sebanyak 12 orang. Materi yang disampaikan antara lain tentang pengenalan kemanan pangan, keuntungan dari memproduksi pangan yang aman, jenis-jenis kontaminasi pencemaran pada pangan (biologi, kimia, dan fisik), serta resikoresiko yang timbul akibat keamanan pangan diabaikan. Metode penyuluhan menggunakan metode focus group discussion (FGD) dengan media LCD proyektor. Dengan diberikannya materi tersebut, diharapkan para pelaku industri pangan dapat meningkatkan pengetahuan dan kesadaran dalam memproduksi pangan yang sehat dan aman.

\section{A. Penyuluhan dan Praktik Prinsip-Prinsip GMP}

Praktik prinsip-prinsip GMP dilakukan sebanyak 2 kali, yaitu pada tanggal 20 dan 21 April 2019. Hal tersebut dilakukan agar kegiatan pelatihan dapat berjalan efektif.

Pelatihan pertama, dilakukan penyuluhan dengan metode FGD dan praktik langsung. Di sini narasumber terjun langsung ke lokasi mitra untuk mendapatkan gambaran aktual dari proses produksi yang dilakukan oleh mitra. Pada kesempatan ini pula narasumber dapat menilai sejauh mana pemahaman mitra terhadap prinsip GMP. Narasumber mengikuti seluruh proses produksi, mulai dari bahan input masuk hingga produk dikemas. 


\section{INTEGRITAS : Jurnal Pengabdian}

Vol 3, No 1, Juli 2019

\section{ISSN 2580-7978 (Cetak) ISSN 2615-0794 (Online)}

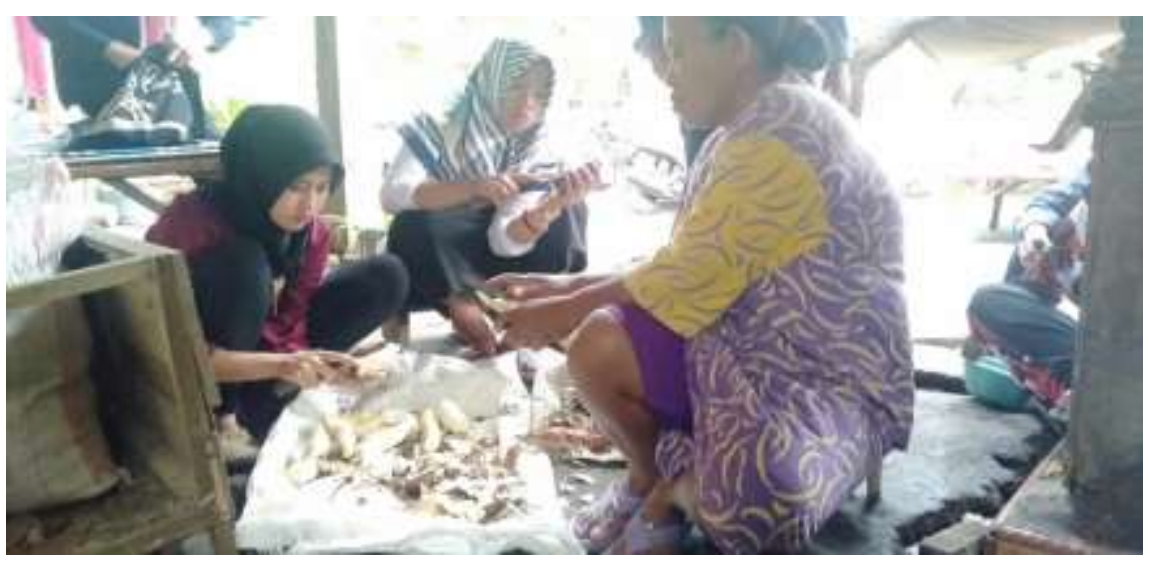

Gambar 2. Proses pengupasan singkong

Gambar di atas tampak proses pengupasan pada produk kripik singkong yang dilakukan oleh karyawan. Secara umum proses pengupasan sudah tepat, karena dilakukan di luar ruang produksi dan dekat dengan sumber air, untuk proses pencucian di tahap berikutnya.

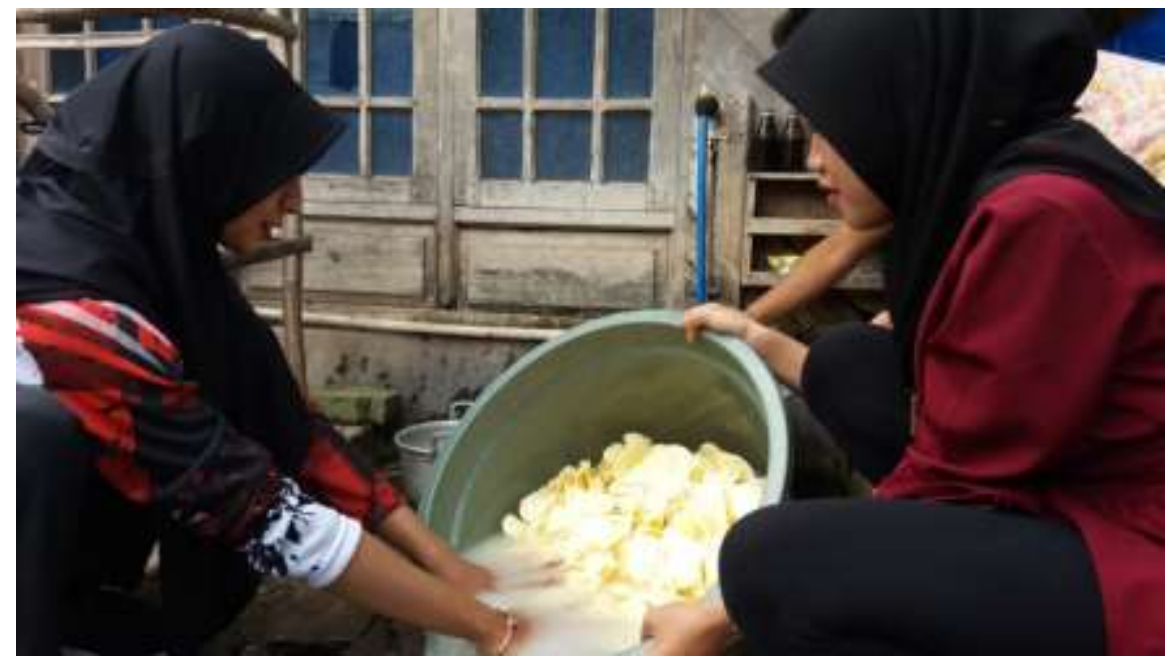

Gambar 3. Proses pencucian singkong

Gambar 3 menunjukkan proses pencucian singkong di home industry. Proses pencucian menggunakan air mengalir dari PDAM. Hal tersebut 


\section{INTEGRITAS : Jurnal Pengabdian}

Vol 3, No 1, Juli 2019

ISSN 2580-7978 (Cetak) ISSN 2615-0794 (Online)

menunjukkan prinsip GMP, terkait dengan sumber air telah dilaksanakan dengan baik, yaitu menggunakan air bersih dan mengalir.

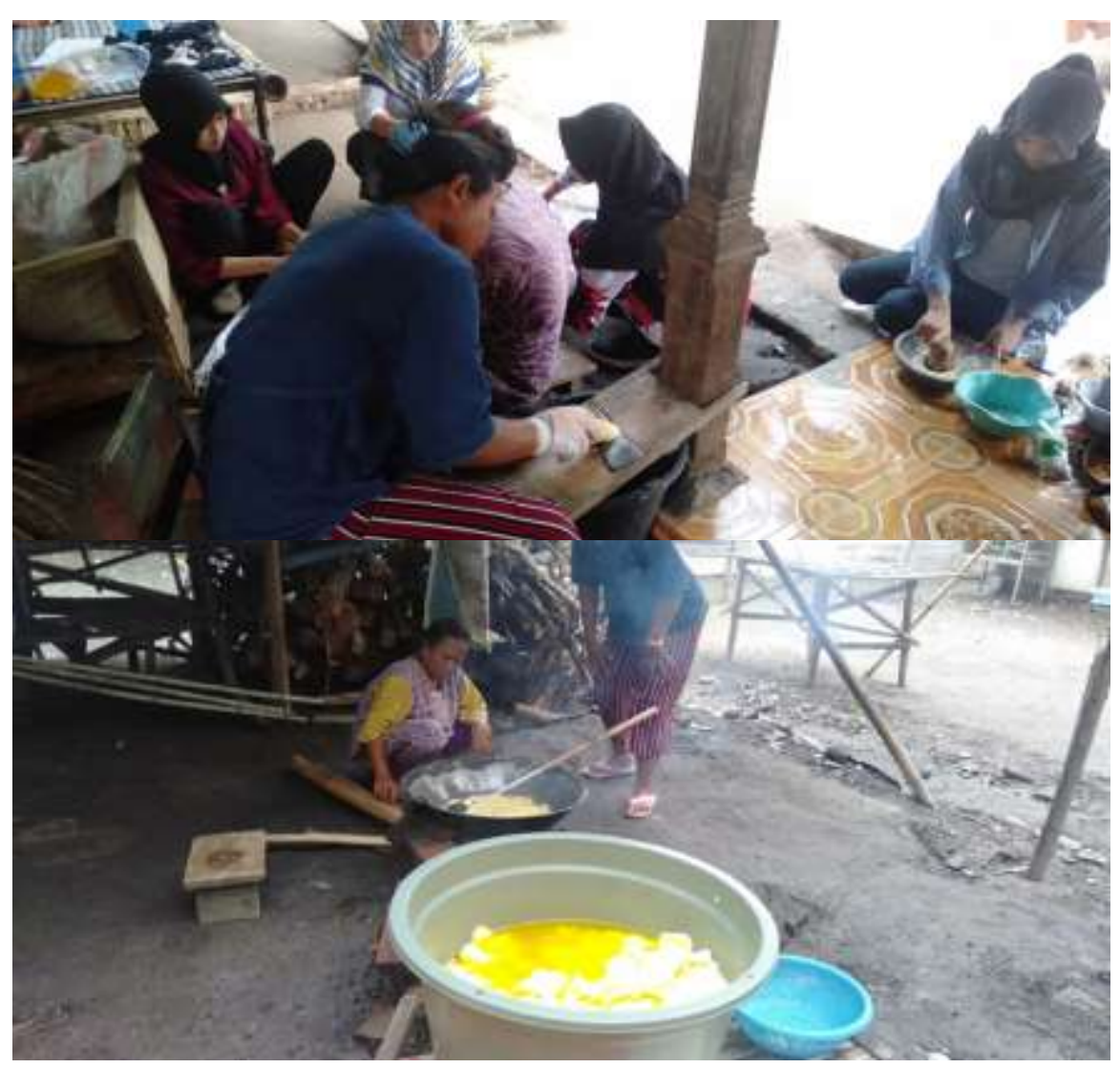

Gambar 4. Proses produksi kripik singkong

Gambar di atas menunjukkan proses pengirisan, pemberian bumbu, dan penggorengan yang dilakukan oleh mitra. Terlihat proses tersebut dilakukan di luar ruangan yang memungkinkan terjadinya kontaminasi pencemaran pangan. Oleh sebab itu, perlu dilakukan pendekatan dan pemberian pemahaman terkait hal tersebut agar mitra dapat memindahkan proses produksinya di tempat yang lebih tertutup, sehingga kontaminasi pencemaran dapat dikurangi. 


\section{INTEGRITAS : Jurnal Pengabdian}

Vol 3, No 1, Juli 2019

\section{ISSN 2580-7978 (Cetak) ISSN 2615-0794 (Online)}

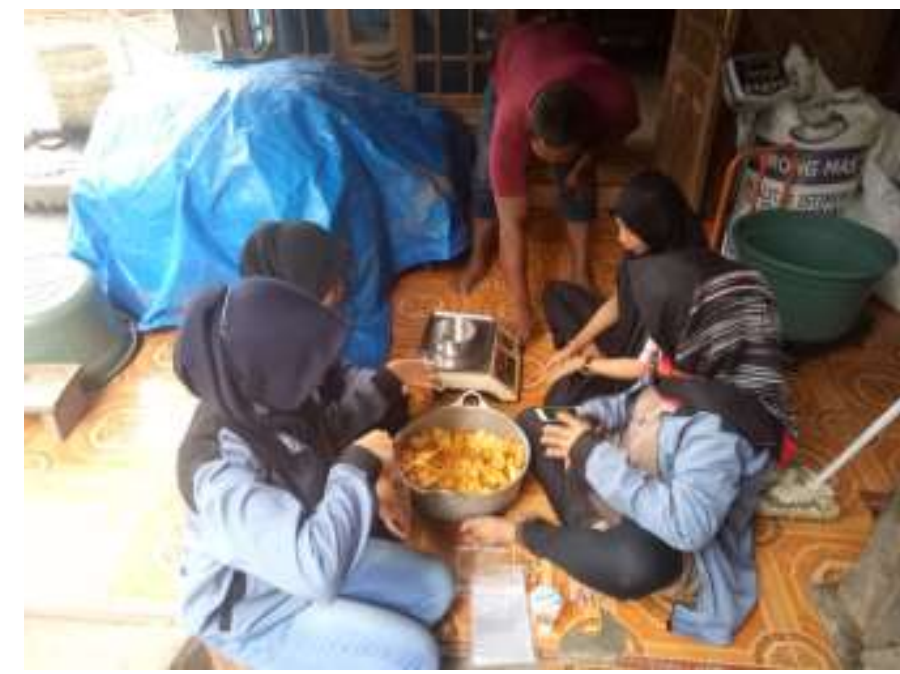

Gambar 5. Proses pengemasan kripik singkong

Proses pengemasan kripik singkong dilakukan di tempat yang terbuka. Apabila diamati lebih seksama, proses pengemasan produk berdekatan dengan input produk. Hal tersebut tentu saja tidak sesuai dengan prinsip GMP yang memungkinkan semakin besarnya resiko kontaminasi silang pada produk. Untuk itu, perlu dilakukan penyuluhan untuk memperbaiki proses pengemasan, sehingga dihasilkan produk yang aman dan sehat.

Pelatihan kedua, dilakukan penyuluhan sesuai dengan hasil evaluasi dari proses prosuksi yang dilakukan oleh mitra, sehingga didapatkan materi yang perlu mendapatkan perhatian khusus, yaitu pada proses pengirisan, pemberian bumbu, penggorengan, serta pengemasan.

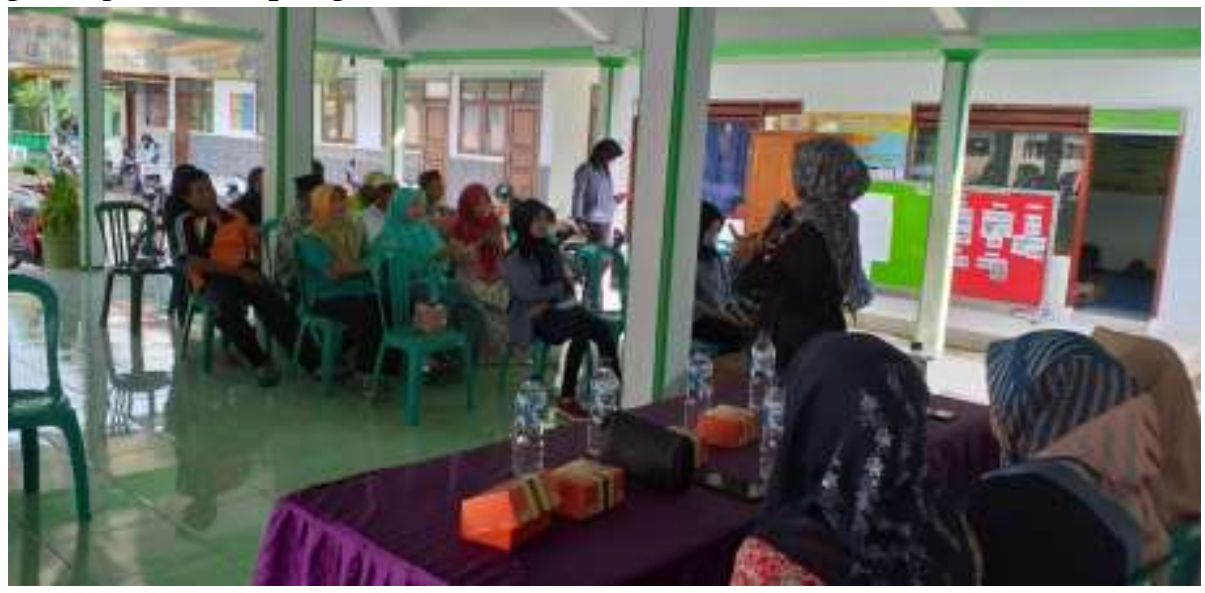

Gambar 6. Kegiatan Penyuluhan tentang Prinsip-prinsip GMP 
INTEGRITAS : Jurnal Pengabdian

Vol 3, No 1, Juli 2019

ISSN 2580-7978 (Cetak) ISSN 2615-0794 (Online)

\section{KESIMPULAN}

Penyuluhan prinsip-prinsip GMP yang telah dilakukan diantaranya, penyuluhan konsep keamanan pangan, penyuluhan potensi kontaminasi pencemaran pangan, penyuluhan resiko pencemaran pangan, dan penyuluhan sekaligus praktik prinsip-prinsip GMP. Pelaksanaan pelatihan berjalan lancar dan antusias yang dihadiri oleh mitra pemilik home industry beserta karyawannya sebanyak 12 orang.

\section{DAFTAR PUSTAKA}

Anonim. 2008. Peraturan Menteri Pertanian Nomor 35/Permentan/OT.140/7/2008 tentang Persyaratan dan Penerapan Cara Pengolahan Hasil Pertanian Asal Tumbuhan Yang Baik (Good Manufacturing Practices). Kementrian Pertanian: Jakarta

Anonim. 2010. Peraturan Menteri Perindustrian RI Nomor 75/MIND/PER/7/2010 tentang Pedoman Cara Produksi Pangan Olahan yang Baik (CPPOB). Kementrian Perindustrian: Jakarta. 